\title{
Small and Medium Enterprises in the Middle East and North Africa Region
}

\author{
Khaled Otman ${ }^{1}$ \\ ${ }^{1}$ Department of Accounting, Faculty of Economics, University of Benghazi, Libya \\ Correspondence: Khaled Otman, Department of Accounting, Faculty of Economics, University of Benghazi, \\ Libya.E-mail: khaled.otman@uob.edu.ly
}

Received: December 13, 2020

Accepted: Janaury 26, 2021

Online Published: April 9, 2021

doi:10.5539/ijbm.v16n5p55

URL: https://doi.org/10.5539/ijbm.v16n5p55

\begin{abstract}
In the Middle East and North Africa (MENA) region, Small and Medium Enterprises (SMEs) are now widely recognized as engines of economic development. This paper discusses the importance of SMEs in the MENA economic area and identifies the challenges and barriers facing SMEs in MENA countries. In addition, this study analyses the effects of two 'black swan' Coronavirus disease (COVID-19) phenomena and a decline in oil prices on the economy of MENA in 2020. The current study found that the most significant challenges were identified as lack of access to finance, lack of managerial expertise, inefficiencies of government, lack of a well-trained workforce, inadequate infrastructure, corruption and bureaucratic obstacles. Among these challenges, the lack of access to finance appears to be the major challenge and suggests that future research is required to identify the role of Islamic finance models in the financing of SMEs in MENA countries. This research provides all stakeholders with policy implications intended for enhancing the different features of SME improvement in the MENA region and generally in developing countries.
\end{abstract}

Keywords: small and medium enterprises, economic development, coronavirus pandemic (COVID-19), challenges for SMEs, middle east and north Africa

\section{Introduction}

SMEs have drawn a considerable deal of attention from researchers and policy makers around the world. Sector plays a significant role in establishing a healthy private sector by an important contribution to jobs and economic development (Rocha, Farazi, Khouri, \& Pearce, 2011). For most economies around the world, particularly developing and emerging economies, SMEs are essential. The World Bank notes that up to $60 \%$ of total jobs and up to $40 \%$ of gross domestic product (GDP) are provided by formal SMEs in emerging economies, and these figures would be substantially higher if informal SMEs were taken into consideration (Karadag, 2015; Ndiaye, Razak, Nagayev, \& Ng, 2018). Moreover, the World Bank also estimates that 600 million people would join the worldwide work force for the next 15 years, especially in Asia and Africa. From this approximate projection, four out of five new jobs are anticipated to be generated by SMEs. Furthermore, a World Bank Group report estimates that there are at least 400 million MSMEs (World Bank, 2011).

Recent empirical evidence indicates that SMEs in high-income countries add to over 55 precent of GDP and over 65 precent of total jobs. SMEs and informal companies provide about 60 precent of GDP and around 70 precent of total workers in low-income countries, while over 90 precent of total jobs and over 70 precent of GDP are in middle-income countries. In the countries of the European Union, for instance, there are about 25 million small businesses, accounting for 99 precent of all businesses; they hire almost 95 million people, generating 55 precent of total jobs in the private sector (Keskin, 2010; Zafa and Mustafa, 2017). As the importance of the SME sector has become clearer in every main economic indicator, especially with regard to the position of such companies in developing new employment, real GDP development and growth opportunities, the SME sector is now the core of socio-economic policies in both developed and developing economies, even leading research in this field to accelerate (Karadag, 2015).

SMEs are now widely recognised in the MENA region as backbone of the economy and as major contributors to all countries' sustained GDP. In MENA nations, the SME sectors is comprised of further than 90 precent of all companies outside the agricultural sector in the region and is mainly involved in the manufacturing and service sectors and create more jobs for both skilled and unqualified people (Makhlouf, 2017). According to the same 
statistical report, for instance, SMEs make up upwards of $95 \%$ of all non-agricultural private enterprises in Egypt and compensate for around three-quarters of the recent generation of workers. Through Kuwait, this sector makes up 90 precent of private labour, comprising labour and imports, an additional 45 precent of labour, jobs and domestic rates of less than 1 precent, producing about 90 precent of employment in Lebanon, more than 95 precent of total firms. In the UAE, SMEs make up around 94.3 precent for country's commercial ventures, employ nearly 62 precent of the population and produce about 75 precent of the state's GDP. Besides, Yemen contributed in place of 96 precent of GDP in 2005, and Algeria, Palestine and Saudi Arabia accounted for about 77 precent, 59 precent, 25 precent in that same year (Emine, 2012).

While SMEs are vital tools towards addressing economic and social problems and meeting development goals, they seem to face considerably higher barriers than large businesses, particularly in developing countries. Matter of fact, World Bank business-level surveys indicate that there is a much smaller proportion of small and medium-sized businesses have a loan or a credit line compared to large companies, and that financial support is much more limited in the lower and middle-income sectors (Rocha et al., 2011). Wang (2016) found that the most significant obstacle was access to finance. Management skills, location technology, corruption, regulatory tax rates, competitiveness, energy and political factors are other important factors; these are close to what could be recorded in the World Bank Enterprise Survey of Emerging Economies. The previous reviewed literature explored the barriers affecting the production of SMEs in developed countries. However, much less attention has been undertaken at underdeveloped countries such as the MENA region. The main aim of this study is therefore to explore the following research questions, what is the role of SMEs in the MENA region's economy, and what determines the main challenges affecting SMEs in MENA countries in developing countries.

In addition, the MENA region faces "Dual Shock" (COVID-19) and a fall in oil prices in 2020. Empty government coffers will make it more difficult to tackle the emergence of the novels influenza virus and its socioeconomic implications. There are significant balance-of - payments and fiscal deficits facing several MENA countries. Many still bear high premiums for sovereign risk, Additional international borrowing in private markets would be challenging for those nations. In addition, nations with national currencies would make it challenging for using aircraft currency as a consequence of the apparent conflict among money printing and peg management. To help negotiate an incredibly rough patch, the region will need a great deal of foreign support (Arezki and Nguyen, 2020). Researchers and policy makers are interested in answering the question, what are the impact of the COVID-19 and the decline of oil prices on the economy of the MENA region, especially for SMEs?'

There are important academic and practical consequences of the current research. The paper discusses the effect on the economy of the MENA region of the coronavirus and the crash in oil prices, particularly for SMEs. This is the first research to examine the effects of (COVID-19) and the fall of oil prices for SMEs on the MENA region's economy. Moreover, despite the enormous academic interest these SMEs have created over the last few years, the literature on finance remains silent in analysing the vital role of SMEs in the MENA economy and in investigating the key challenges facing SMEs in developing countries, especially in the MENA region. Thus, by exploring the problems of SMEs in emerging economies, this study aims to fill a significant gap in the literature.

In this research, the effects of the Coronavirus pandemic (COVID-19) and the price of oil on the MENA region's economic development, as well as international definitions of SMEs, were discussed in Section 2. Section 3 describes the important role SMEs can play in the development of the MENA region. It also analyses the challenges that SMEs face in the MENA region in Section 4 and in Section 5 presents discussion and concluding remarks along with policy suggestions.

\section{Literature Review}

\subsection{The Effects of Two 'Black Swan' on the Economy of MENA}

MENA countries are facing COVID-19 and a reduction in crude prices. In 2020, two black swan' phenomena are concurrently battering economies around the world: the COVID-19 epidemic and the Russian-Saudi Arabia oil price battle. Naturally, the MENA nations are indeed impacted, though each in various ways. COVID-19 is hit hard by those who are net energy consumers who should have gained significantly from the considerably lower energy prices, Though oil companies are dealing with an all-out oil price battle, the severe decline in global demand caused by the pandemic has intensified (Seznec, 2020). Given the outbreak of the COVID-19 virus and its wide-ranging effects on global supply chains, foreign trade and also demand, investment and industrial activities, the world and the MENA economies are suffering extraordinary circumstances in 2020.

The virus raised levels of confusion and reduced business and consumer confidence. In several nations around the world, the restrictions placed on transport have a negative effect on tourism, aviation, commerce, 
manufacturing and other economic sectors. At the beginning of 2020, the projections of some international organizations suggested that if the virus is contained in the first quarter of 2020, the effects of the virus on the global economy would be marginal, below 0.1 percentage points of global GDP. Other predictions, however, have indicated a further downturn in world economy, with global economic growth projected to fall to about half of the expected rate before the emergence of the virus. Eventually, it became apparent later that the global economy had reached a time of depression poorer than those of the world financial crisis (The Arab Monetary Fund [AMF], 2020).

In regard to the oil price shock, the failure of negotiation between the Organization of Petroleum Exporting Countries (OPEC) and its partners has contributed to what is probably to become a continuing breakdown in the price of oil. On 5 March 2020, OPEC announced a supply decrease of 1.5 million barrels per day (mb/d) for the 2nd period of 2020, of which $1 \mathrm{mb} / \mathrm{d}$ will come from OPEC countries and $0.5 \mathrm{mb} / \mathrm{d}$ would arrive from non-OPEC related suppliers, particularly Russia. Russia rejected the proposal next day, leading Saudi Arabia, the world's largest oil producer, to increase its maximum potential capacity to $12.3 \mathrm{mb} / \mathrm{d}$. Saudi Arabia also announced unprecedented concessions of nearly 20 precent in key markets. The consequence had been a sudden drop of more than 30 precent in prices and ongoing decreases since. The average West Texas Intermediate (WTI) oil price declined considerably of \$22.39 per gallon in the equity market session on March 20, 2020, below half of the cost at the start of the month. The futures graph shows that the market expects a slow recovery in crude prices, not reaching $\$ 40$ each gallon through the rest of 2022 (Figure. 1).

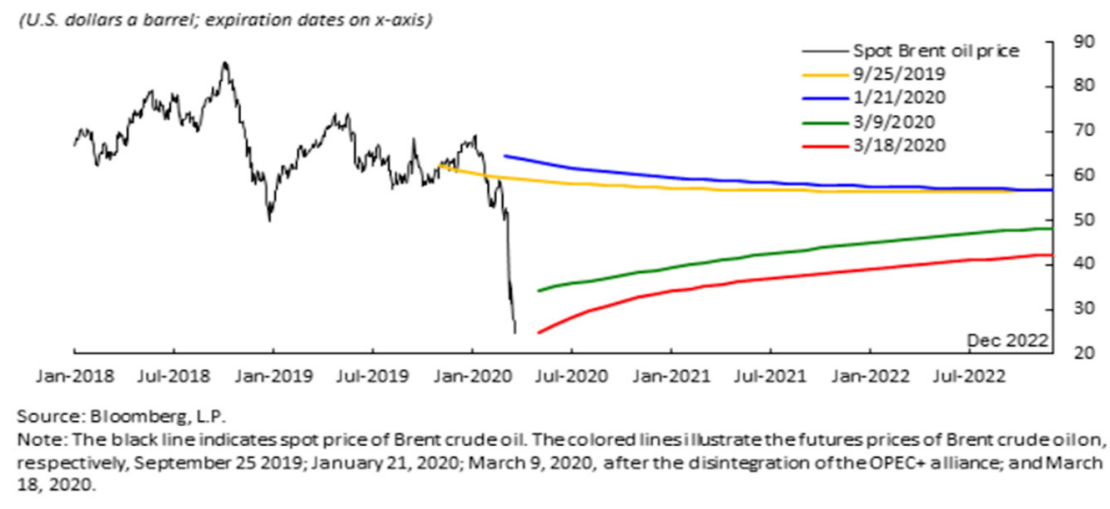

Figure 1. Spot and forecasts of brent oil price

Fewer costs are usually better for oil-importing nations and worse for oil - exporting countries, especially for MENA nations. Measuring the gap between supply and demand (net oil export market) by the precent move in the cost of crude as a percentage of GDP is a simple way to get an idea of the size of the actual revenue result of the shift in oil prices. For instance, Kuwait, when total oil output amount towards 43 percentage of GDP, will suffer a real revenue decrease of around 20 precent of GDP on the prospective assumption that crude prices will remain 48 precent just under the 2019 rate, while Morocco's importer will see an overall revenue increase of 3 precent of GDP, Figure 2. Back-of-the-envelope effect of the oil collapse (Arezki and Nguyen, 2020).

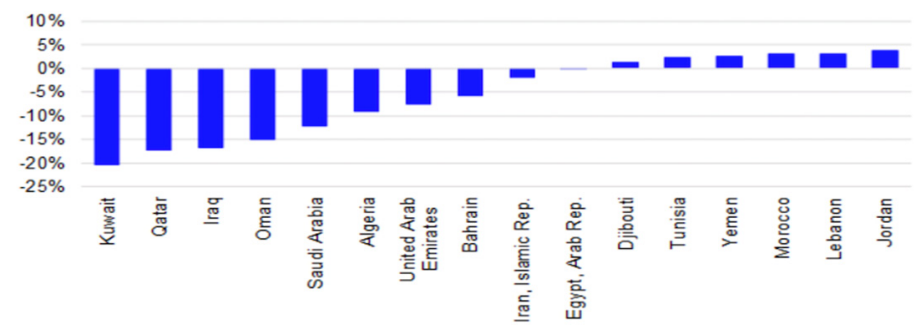

Figure 2. Back-of-the-envelope effect of the oil collapse

Source: Graph extracted from the World Bank. 
In addition, changes in the international oil markets would affect Arab-exporting countries. As a consequence of the outbreak of the virus and the subsequent surplus production, the expected lower oil demand levels will result with a further decrease in international oil prices in 2020. The oil industry which, accounts for about 27 precent of Arab countries' GDP, 42 precent of total exports and 62 precent of total public revenues, will consequently be adversely affected. The external demand shock, which will reduce foreign exchange receipts as a consequence of the anticipated decrease in exports of goods and services and also remittances increasing to more than $10 \%$ of GDP in some of these countries, will affect Arab oil importing countries. Additionally, in some countries that implement flexible exchange rate regimes, national currencies may face downward pressures, which will increase the cost of foreign debt services (AMF, 2020).

The economy of the region is anticipated to contracting by 5.7 precent, with some conflict nations' economies shrinking by more than as 13 precent, resulting in a total loss of US\$ 152 billion. The IMF has lowered its region economic forecast to its lowest rate in 50 years as a result of the pandemic and low oil prices. The MENA stock market has lost $23 \%$ of its value, depriving the region of finance that could have been invested in the process of recovery. In a region where 14.3 million people are already unemployment, the International Labour Organization (ILO) predicts that by the second period of 2020, the country will have lost the amount of 17 million full-time jobs. There are 55.7 million people in the region who require humanitarian aid, including 26 million people who have been internally evicted. Due to a lack of hand washing equipment, 74 million people are at a higher risk for getting the virus. To address the risks and influence of the COVID-19 pandemic on the most disadvantaged people in countries impacted by humanitarian disasters or otherwise at risk, an urgent $\$ 1.7$ billion is needed in 2020 alone(The United Nations Office for the Coordination of Humanitarian Affairs [UN OCHA], 2020). See Figure 3. Estimated Impacted of the Coronavirus Pandemic in the Arab Region.

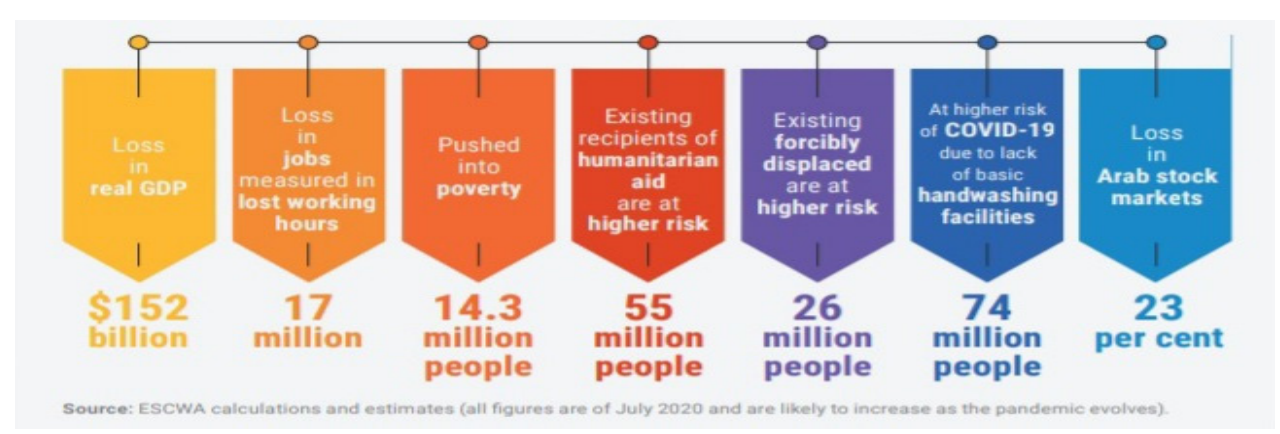

Figure 3. Estimated impacted of the coronavirus pandemic in the arab Region

SMEs around the world are experiencing major disruptions in their activities due to the implementation of containment and social distancing measures in many countries, reduced demand and fragmented supply chains, and confusion as to how deep and how serious the problem will be. Small businesses operating in hard-hit industries, such as tourism, and those engaged in the provision of face-to - face services, such as cafes, restaurants, stores, personal services, repair shops and others, are especially concerned with this. Furthermore, small and medium-sized companies that have minimal or no access to digital technology given the lack of technological, financial or human capital are often disrupted or significantly reduced in their operations due to the difficulty of operating remotely. In 2020, two 'black swan' phenomena are concurrently battering economies around the world: the COVID-19 virus and the oil price war between Russia and Saudi Arabia. Of course, the MENA nations are also influenced, though each in various ways. COVID-19 is hit hard by those that are net energy consumers who should have gained significantly from the considerably lower energy prices, while oil and gas companies struggle from an all-out oil price war made worse by the dramatic drop in global demand induced by the pandemic (The Organisation for Economic Co-operation and Development, [OECD], 2020).

In short, it is possible that the two black swan incidents will strike the MENA region quite difficult. The cumulative impact of the pandemic and the armed conflict on oil prices will possibly resulted cash reserves and decrease, if not mitigate, economic growth. In addition, the socio-economic costs for the people of the region also are high and their hardship is great, and both will only worsen in the short term. Of necessity, if the disease outbreak begins to abate by the summer and Russia and Saudi Arabia come to an understanding, it is probable to restart certain ventures that have been mothballed. Enthusiasm may be returning. Long-term concerns, however, such as the conflicts between Iran and the countries of the Arab Gulf, the based on inter-GCC dispute, the 
tensions in Yemen and Libya, and the continuing issues between Morocco and Algeria, among others.

\subsection{International Context of Definition of SMEs}

SMEs don't have a definition generally accepted. Some studies define them in context of their total revenue, and some use employee numbers as a measure. It varies from country to country and also between industry and sector. Many countries or organisations, depending on the reason for which they are defined, describe SME differently (Piperopoulos, 2016; Dar, Ahmed, \& Raziq, 2017). Some studies have recognized SME as the number of people working, total organization assets, and the company's sales turnover (Abor and Quartey, 2010, $\mathrm{Hu}$, Mason, Williams, \& Found, 2015; Perera and Chand, 2015). SMEs are commonly considered to be 'enterprises with such a fairly small market share, controlled in a personalized manner by shareholders or part-owners and not through a structured management team; and behaving as separate entities in the context that they are not part of a bigger enterprise or group' (Storey, 1994). The SME has conceptual issue, so that each nation or entity seems to have its own meaning to fit their requirements. Therefore, whether a business is a SME or not can differ substantially from one perspective to another, perhaps even differing between organizations of the same country (Karadag, 2015).

The subsequent SME categorization definition was introduced by the OECD: micro: 1-4 employees; very small: 5-19 employees; small: 20-99 employees; medium: 100-500 employees; 5. For instance, in certain OECD countries the size of the work force is considered to be the key criteria. Nevertheless, what is known as a small manufacturing business will employ up to 50 people in Belgium and Greece, upwards to 100 in the U.s, up to 200 in Canada, Italy and Spain, and close to 500 in Denmark, France, Germany and Ireland. In almost all of these nations, companies with fewer than ten or lesser to twenty workers are just called very small companies (Ayyagari, Beck, and Demirgüç-Kunt, 2003). In addition, SMEs are considered to get more to 1,000 workers in such companies in China, but the drop-off even for industries in Thailand is up to 200 employees. Additionally, in same state, government bodies may use various conceptions. For instance, one definition may be used by a department, while another is used by the state statistical bureau, and others may be followed by a credit policy.

In the UK, the requirements for becoming a small or medium-sized undertaking are laid down in Articles 382 and 465 of the Companies Act 2006. The Act identifies a SME as one with a profit not exceeds $£ 6.5$ million, a balance sheet total not exceeding $£ 3.26$ million and not reaching 50 workers, while a medium-sized business has a revenue not increasing $£ 25.9$ million, a balance sheet total not exceeding $£ 12.9$ million and not exceeding 250 staff. (Ervine, 2013). Nevertheless, the standard rule is to identify smaller firms with employees from 0-49, a medium-sized company with employees from 50-249, and a large business including employees equal to or greater than 250. Small and medium-sized businesses are also generally described as firms employing 0-249 people. In Japan, the upper limits for the manufacturing, building and transport industries are placed at 300 million JPY for assets and 300 for the number of workers, while the upper limit for resources for the service sector is 50 million JPY and the estimate for workforce is 100 (Chusho, 2014; Karadag, 2015).

The ILO describes SMEs as units from which goods and services are manufactured and supplied. They are managed by personality independent workers in metropolitan areas of the developed world. Some may employ labourers or craftsmen. Many of them always use lower bandwidth, generating erratic income, and creating volatile job opportunities, including limited fixed resources without current assets. Most of these firms are also not registered with government departments, and no data is provided in government figures ILO, 2017). Similarly, the concept of the United Nations Industrial Development Organization (UNIDO) for Small Enterprises (in emerging nations, the small firm consists of 15 to 19 staff based on the regular number of employees. The medium employs 20 to 99 people, and the large number of employees recruiting more than 100 people (UNIDO, 2017).

The concept of SMEs by the World Bank is that micro scale; smaller than 50 employees; 50 medium-sized workers; 50-200 staff. In line with the European Commission (EC) concept of SMEs, the number of employees hired by the company was used to describe SMEs. According to the EC concept, micro-enterprises are businesses with 0 to 9 workers; 10 to 99 employees are small enterprises, whereas medium-sized enterprises are enterprises with 100 to 499 employees. In Denmark, France, Germany and Ireland as many as 500 companies with less than 10 or less than 20 workers in almost all of these countries are either known as being very small businesses (Abor and Quartey, 2010). In general, there seems to be no common concept of SMEs across officials of intergovernmental development organizations, every considered in within agreed meaning of its own agency, following Table 1 shows meanings of SMEs used by Multilateral institutions. 
Table 1. SME Definitions

\begin{tabular}{llll}
\hline Institution & $\begin{array}{l}\text { Maximum \# of } \\
\text { Employees }\end{array}$ & $\begin{array}{l}\text { Max. Revenues or Turnovers } \\
(\$)\end{array}$ & Maximum Assets \\
\hline World Bank & 300 & $15,000,000$ & $15,000,000$ \\
MIF- IADB & 100 & 3,000000 & (none) \\
African Development Bank & 50 & (none) & (none) \\
Asian Development Bank & No official definition. Uses only definition of individual national governments \\
UNDP & 200 & (none) & (none) \\
\hline
\end{tabular}

Source: (Gibson and van der Vaart, 2008, p5).

In the MENA countries, SMEs represent a wider variety of meanings and interventions, ranging from nation to nation and between the reports of SME statistics. Some of the widely utilized requirements are staff numbers, total net assets, amount of revenue and expenditure. The most general interpretive framework employed, nevertheless, is jobs, and here again there is variance in the concept of the SME's top and bottom size limit. Given this variation, a large number of sources describe SMEs to have a 0-250 employee cut-off range. In Yemen, for instance, a small company employs less than four employees, a medium-sized company employs between two and nine employees and a large company employs more than 10 people. A small company is one with about four and ten employees in Jordan, and a medium-sized business seems to be of 10 to 25 workers. Micro-enterprises are those employing up to four staff. A SME in Egypt is a funded-in amount of no more than LE1 million and no more than 50 employees (Emine, 2012).

In general, there is no internationally agreed concept for small and medium-sized companies. There is consensus on the specifications for the different sizes of industry that could be listed. The most famous indicators are those with the many common measures (Elhassan, 2019):

Number of workers: This is considered the easiest criterion for description and the most common criterion for simple measurement and comparison in industrial statistics. The drawbacks of this concept vary from country to country and thus do not consider the technical gap in output.

Investment scale: In many countries, the investment capital remains a represents for separating between SMEs and huge industries, provided that the investment volume allows a quantitative image of industrial production degree.

Annual Sales Value: One of the parameters that characterize industries in terms of production volume and competition in the markets can be considered.

\section{The Importance of SMEs for Economic MENA Countries}

A vibrant SME sector could play a major part in resolving economic problems. SMEs are, in specific, a main source employment in emerging and developing countries, estimated to account for about $45 \%$ of jobs created (Ayyagari, Demirguc-Kunt, \& Maksimovic, 2014). The importance of SMEs to GDP in MENA economies consists of four to 40 per cent, highlighting either the opportunities for higher position for SMEs in such regions and their also major role in another. It is projected that SMEs contribute for 80-90\% of MENA-region businesses (Stepanyan, Abajyan, Ndoye, \& Alnasaa, 2019). In the MENA countries, about \% (MSME Country Measures, 2014), and intensity (entity per 1,000 people) given more weight to micro-enterprises (Gonzales et al, 2014). For instance, in 2011 the amount of MSMEs in Jordan and Tunisia was about 25 and 56 MSMEs per 1,000 people respectively, 23 and 55 of which were micro-enterprises, see Figure 4. Micro, Small and Medium Size Enterprise Density (The International Monetary Fund [IMF], 2019).

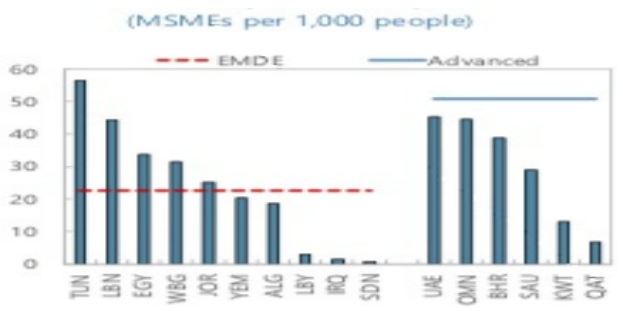

Figure 4. Micro, small and medium size enterprise density

Source: (IMF, 2019). 
SMEs seem to be a very high part of the economies of the MENA countries when the GDP influence is $35 \%$. This same region has more than 10 million establishments that drop within the SME category. In the non-agricultural sector, $90 \%$ of micro and small enterprises contribute to 80percent of all employment. These numbers simply illustrate the crucial role of vital role in the economic development of the MENA region. Nevertheless, according to the OECD (2000) and the Asian SME Summit (2009), SMEs represent a large percentage of Businesses worldwide and perform incredible in the creation of jobs, the production of services and products, providing a decent living conditions and leading enormously to the national income of many countries. In 1996, the European Commission led directly to the word SME and described it as companies employing just fewer than 250 employees (Burns, 2001). For the various countries in underdeveloped nations, Enterprises remain diversely represented. The term Enterprises cover a diverse business group in a developing nation, ranging from a single artist employed in a small shop making handicrafts for a trade fair to advanced engineering companies that sell on international trade (Fischer and Reuber, 2003).

SMEs are giving an ability to improve on the demographic wealth of the region. SMEs make up a large portion of formal jobs in many economies in the region, including Iraq, Lebanon, Sudan, Gaza and the West Bank, and Yemen, where more than $50 \%$ of private sector jobs are in SMEs (Figure 4). When taking into account the informal sector, that share is probably higher. At same time, youth and women unemployment rates remained above 20 and $17 \%$ (ILO), in both, and workforce attendance rates did not exceed 34 and $27 \%$ since 2010(International Labour Organisation statistics [ILOSTAT]), respectively, during the same time span. With young people accounting for about one third of the population, SMEs will contribute to the jobs available required by the private sector to bring in new job market entries, see Figure 5. SME Sector in the MENA Region (IMF, 2019).

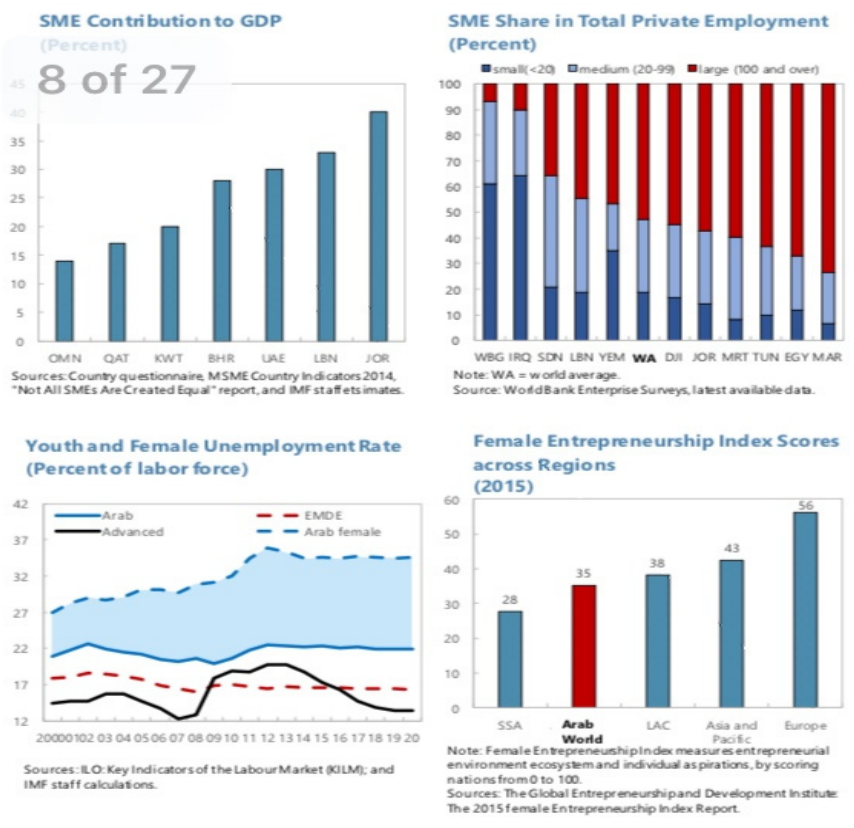

Figure 5. SME sector in the MENA region

Source: (IMF, 2019)

SMEs are generally the backbone of many MENA countries' industrial development, and play a key role in increasing the national economy. In Egypt, SMEs companies compensate for over $90 \%$ of the overall growth rate, $65 \%$ of workers and $47 \%$ of industrial profit generated, while in Yemen, SMEs accounted for $95 \%$ of total manufacturing organizations and add $45 \%$ of workforce and $18 \%$ of value to the economy added. SMEs' impact to overall growth in terms of economics is strong all over the country. These were reported that SMEs add 50\% of Moroccan manufacturing GDP and offer $82 \%$ of total jobs in the manufacturing sector. SMEs make up over $92 \%$ of all businesses in Jordan and represent 63 per cent of the value-added sector (Mahmood, 2008).

As per Dubai National Bank, The Essence of SMEs in MENA nations, SMEs and micro-enterprises account for 
further over 90percent of all non-agricultural businesses, generating a large share of GDP. In Morocco, for instance, 93 precent of manufacturing firms are Small and medium enterprises, responsible to $38 \%$ of development, 33 percent of expenditure, $30 \%$ of exporting and $46 \%$ of employment. Companies with fewer than 100 workers in Bangladesh account for over 90 precent of companies and around two - thirds of jobs. Likewise, 99 per cent of all private businesses in Ecuador get less than 50 workers and accounted for 55 per cent of employment 4. Not all of these small and medium-sized enterprises are in the organized sector; others exist in the unregulated labour marketplace, varying in range from about $4 \%-6 \%$ in advanced countries to more than $50 \%$ in growing countries, see Figure 6. SME contribution to employment and GDP (Emine, 2012).

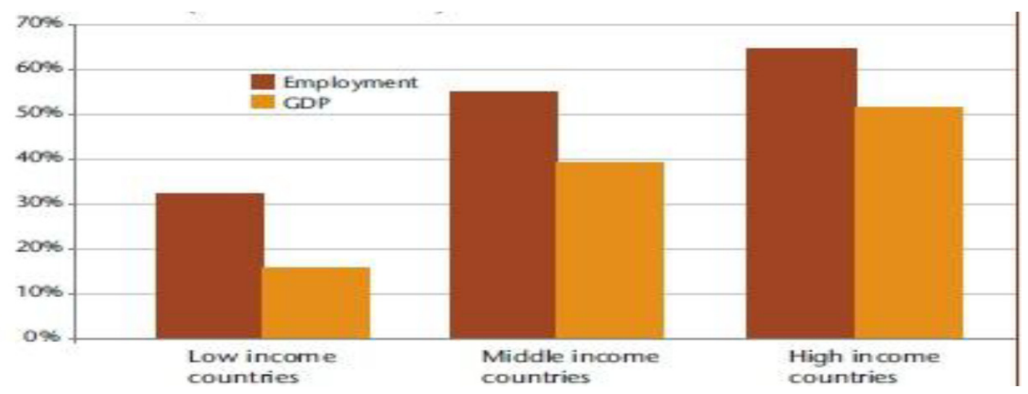

Figure 6. SME contribution to employment and GDP

Source: (The World Business Council for Sustainable Development [WBCSD], 2007).

There is indeed a vast piece of literature on the impact SMEs make to growth. Although not necessarily without some contentious areas, strong consensus would occur on the following facts (Luetkenhorst 2004):

-SMEs (in aspect due to various their industrial sub-sectors and product types) appear to recruit more labor-intensive manufacturing methods than major businesses. They thus make a major contribution to the development of sustainable job prospects, income generation and, eventually, poverty reduction. This ensures that individual nations and the global institutions as a whole will make efforts to achieve the Millennium Development Target of poverty reduction by 2015 by endorsing SMEs.

There is adequate verifiable research that countries with higher share of small manufacturing firms have managed to make the wealth distribution more equal (regional and functional). In essence, this is the key contributor to forward social cohesion by minimizing the burden of former redistribution and reducing the gap in income between cities and towns.

Small and medium-sized enterprises are essential for the transition towards farm-driven to industrialized countries, as they provide basic prospects for valuation development processes that could generate livelihood opportunities. The prevalent position of women in this background is of key significance.

Small and medium-sized businesses are the base for entrepreneurial development, innovation and portfolio and lay the foundations to lengthy growth trends and the transition to big firms.

SMEs are helping to create structural adaptive capacity. They contribute to the containment of productive capital at all economic levels and lead to the improvement of stable economic structures that are interconnected between big and small businesses.

These relationships are also increasingly important for attracting foreign investment. Investing TNCs are searching for dependable local production for their production processes. In competition for foreign investors, therefore, there is an emphasis on the nature of local related industries.

SMEs are an important source of creativity and often manufacture goods in specific regions in a flexible production and customized way, as is commonly demonstrated in technological tools.

As the non-exhaustive list above shows, the growth accomplishments of small and medium-sized enterprises are diverse and could be discovered at the crossroads of social and economic aspects: SMEs promote economic stability by linking and supporting bigger companies, by fulfilling smaller businesses and in particular, by contributing to structural development capacity building.

\section{Key Challenges of SMEs}

Much of the SMEs success worldwide has been published and studied. Nonetheless in addition to many studies 
on SMEs, several literatures has paid sufficient attention to issues faced by these companies in term of providing knowledge and guidance to company directors and businesses to increase their market share. SMEs struggle established which prevent the growth. The literature here identified six main constraints of SMEs growth: (1) lack of finance; (2) innovation and technology; (3) infrastructure and government support; (4) skilled human resource insufficiency; (5) firms characteristics; and (6) poor management (Wang, 2016; Muriithi, 2017; Emine, 2012; Karadag, 2015; Ndiaye et al., 2018). This section presents a brief literature overview of the recent main challenges which may influence the value of SMEs, especially in developing and emerging economies.

\subsection{Lack of Finance}

Finance is a main challenge for small and medium-sized businesses, and can have a direct impact on their performance. SMEs do not even have comprehensive financial information, and then are usually not needed, and are categorized as 'informatively opaque'. Since these, relative to their large peers, small and medium-sized enterprises are seen as a more vulnerable opportunity and continue to experience higher costs or onerous security conditions from financial institutions (Wang, 2016). Access to finance has been identified as a major challenge to development; focus on high growth companies related to the World Bank Enterprise Survey database across 119 third world countries (Ndiaye et al., 2018). Several previous studies have established the lack of resources as a major barrier to SME growth in developing countries (Ayyagari, Demirguc,-Kunt, \& Maksimovic, 2006; Beck, Demirgüç-Kunt, Laeven, \& Maksimovic, 2006). Lin (2007) reported that more over $98 \%$ of small and medium-sized enterprises still don't have entree to appropriate funding. Shen, Shen, Xu, \& Bai (2009) found out that China's SMEs receive just $12 \%$ of the resources from bank loans, whereas the counterparts raise 21percent in Malaysia and 24 precent in Indonesia. The absence of sufficient financial resources has become the greatest barrier to SME development. Lin argued that as SMEs are mostly labour-intensive businesses, when faced with credit restrictions, their ability to bear labour costs are diminished. Bari, Cheema and Haque (2005) identified financial shortages as a main barrier in the enhancing of SMEs in Pakistan and India.

\subsection{Innovation and Technology}

Technological innovation can be seen as an instrument for enhancing a nation's competitiveness (Sikka 1999). Through developing the technical capabilities of workers, SMEs will significantly boost their production capabilities and profitability. New technologies are evolving quickly; technologies have improved productivity and giving better manufacturing. Technological innovations give businesses revenue source enterprises Innovation is sometimes viewed as a significant component of business performance. For instance, Subrahmanya, Mathirajan, \& Krishaswamy (2010) showed that innovative SMEs increased development in total of sales turnover, job growth and investment in the automotive parts, electronics and device tools industries contrast to individual SMEs in India. Technological capabilities are benefiting SMEs in many aspects according to Morse, Fowler and Lawrence (2007). Technologies improve small and medium-sized business performance, rising costs and expand customer presence, both locally and internationally. Several studies: (Lee 2001; Romijn 2001; Yusuf, 2003) considered low technology abilities as a key restraint in emerging countries' SMEs growth. The relationship between innovation and performance was discovered by Rosenbusch, Brinckmann, \& Bausch (2011) to be perspective and dependent on the position of innovation and the historical aspects. The study concluded that technological innovation's effect leads to improved SME performance relative to findings from process innovation, such as the history of Expenditure. In addition, the researchers noted this technology seems to have the greatest impact on collectivist-defined national cultures, especially in several Countries in Asia; whereas in more collectivist societies such as the USA, the relationship between innovation and success is poorer.

\subsection{Infrastructure and Government Support}

In many other underdeveloped countries the poor infrastructure gives more to be desired. The disparity in infrastructure availability has affected supply chains in the production sector, in particular the capacity of SMEs to perform on the international economy (Obokoh and Goldman, 2016). Poor infrastructure thus could also have a major effect on firm success. This seems to be particularly relevant in developing countries where urban or region resources could be unformed or poorly developed. Mambula (2002), for instance, clarified that inadequate infrastructure including poor roads, insufficient water supplies; unreliable electricity supply and weak communications networks are challenges to progress for SMEs. Saqib (2014) argued that infrastructural development for economic success of SMEs is a method contained in institutional structures centred on the site and that the effective consequence of this mechanism is focused on leadership ability where participants (individuals, organisations, teams) get the ability to empower capital, impact peers and readjust state policies. The absence of sufficient infrastructure implies that companies would have to bear the cost of acquiring these service providers. Ahmed and Chowdhury (2009) also urged the government to facilitate the provision of the 
necessary electricity, water, roads and highways to promote the success of SMEs in Bangladesh. Likewise, Akuru and Okoro (2014) stressed the possibility of building SME settlements or communities in Nigeria to encourage manufacturing areas. This planning process will make it more competitive to provide necessary services, such as electricity, required for turn-off and operations. In comparison, the lack or loss of infrastructure will lead to SMEs failing. In the context of wage frameworks, taxes, licensing, opportunities, technical assistance and services, the government-created environment redevelops the direction for SMEs to survive and thrive. Based on the legal frameworks introduced by the government, it might quickly crush or stimulate small company economies (Kamunge, Njeru, \& Tirimba, 2014).

\subsection{Skilled Human Resource Insufficiency}

Not only are trained workers more active, however they also provide more training and creative skills (Batra and Tan, 2003). It is possible that those SMEs with more competent staff would be better effective (Hewitt and Wield, 1992). Researcher has described low capacity for natural capital as a major obstacle to the growth of SMEs (McElwee and Warren 2000). Thus the efficiency of a company also depends on the skills and know-how of its employees' human capital. Human capital in MENA SMEs is usually poor in terms of their market analysis, product marketing innovation knowledge and skills, and also some business finance and investment strategic planning. Consequently, the need is to develop sustainable development plans to enhance human resource skills for entrepreneurship and business management in SMEs and to increase the accuracy of SMEs. Thus the entrepreneurial skills can be built through schooling, understand precisely then practice (Hussain, Farooq, \& Akhtar, 2012). Businesses with multiple and quite well workers are therefore significantly more successful because of their increased ability to absorb and use new technology effectively. Unemployment rates range from around $46 \%$ high in Algeria to $6.3 \%$ low in the UAE. Nonetheless, several studies have identified low human potential and skills as significant issues facing SMEs in most developing countries (Batra and Tan, 2003; Bouazza, Ardjouman, \& Abada, 2015). This challenge is much more severe in top management, where the lack of essential skills and knowledge constitutes a strong concern for SMEs and others parts of the world (Lee, 2001; Pasanen, 2007; Aylin, 2013).

\subsection{Firms Characteristics}

The literature focussed primarily on developing economies but failed to find consensus. Although, Ayyagari et al., (2014) have recently found indications that smaller firms are an important source of job growth, Dong and Men (2014) found that considerably younger companies faced severe capital difficulties in developing countries that would in effect, have an adverse impact on growth, sustainability and profitability. Quartey, Turkson, Abor, Iddrisu, 2017; Ndiayea et al., 2018 have found evidence that the effects of company characteristics, such as company size and age, suggest that company size is a significant element of financing in developed countries, which can therefore affect the functioning of SMEs. There are several attributes of company features, in addition to size and age that can impact SME profitability, such as form of ownership and legal standing. The study shows that young businesses were very dependent on indirect funding than on bank loans. Financial funding increased slowly with age, while indirect finance dropped steadily with age. New businesses have been shown to use personal assets twice as much as older companies as leverage, which is close to the results of a US small business study (Avery, Bostic and Samolyk, 1998).

\subsection{Poor Management}

Weak management is a big problem facing companies from all regions of the world. This stems from the lack of strategic experience by most SMEs owners or their executives. Since many business owners lack proper training and experience to manage their companies, their leadership style relies solely on mistakes and is influenced by success and brief profits with little to do with policy planning (Muriithi, 2017). Poor management issues have controlled both developing and advanced nations. A significant reason of company collapse in the US and a direct result of retail bank failures in the 1930s, the phenomenon of poor management had been considered. The challenges persist and are correlated with $92 \%$ of US company failures and $96 \%$ of Canadian collapses and $80 \%$ to $90 \%$ of SMEs showed fails within 5-10 years in Australia and England (Zimmerer, Searborough, \& Wilson, 2008; Ahmad, Rani, \& Kassim, 2011; Khalique, Isa, \& Ageel, 2011). Some many studies have identified some many regulatory roles as being accountable for failures. These aspects involve SMEs that are unable to control: credit management finance, cash flow management, accounting abilities deficit sales \& marketing and human resources, inventory management (Bowen, Morara and Mureithi, 2009). It is interesting that some companies have functional plans and are knowledgeable in their particular fields but possess any management skills or experience of how to run a company. The result was incompetent management and SME performance. Better training and education enables SME executives to be effective in the enterprises according (King and McGrath, 
2002; Brink, Cant, \& Lightelm, 2003; Muriithi, 2017). Specific management and IT skills training is necessary for successful corporate practices. Proper leadership incorporates planning, organising, managing and control, processes critical to the smooth functioning of SMEs, sustenance, development and growth. Until trained and skilled workers are placed in place, the performance management will still not be effective either. The shortage of effective leaders continues to be a major constraint on the development of SMEs and needs particular attention if these companies are to sustain (Nag and Das, 2015).

In MENA region, SMEs typically face a wide range of challenges, despite government and multilateral funding. Such challenges are faced throughout each development process and are generally internal (lack of managerial expertise among proprietors) and external (lack of finance, inefficiencies of government and infrastructural concern. Challenges encountered by SMEs vary across countries due to variations in level of growth, mark of social progress, efficacy of government and current state of affairs in the countries concerned. Many key challenges include the absence of a well-trained workforce, inadequate resources, fraud and bureaucratic barriers. Nonetheless, the greatest obstacle is access to funding. SMEs at various growth levels face significant obstacles when accessing finance. When seeking funding; there are concerns about restrictive interest rates, high debt rates and bureaucratic barriers. This is because there are government-sponsored financing projects, start-ups and private equity money to fund SMEs in multiple nations (Makhlouf, 2017).

Recent research on more than 130 MENA banks has been carried out by the World Bank and the Union of Arab Banks, showing that just 8 precent of debts go to SMEs around MENA, and even less than 2 precent in GCC region. This is slightly lower than the average of 18 precent for middle-income nations and 22 precent for high-income countries. In MENA, SME financing is constrained by the lack of an adequate environment, legislation is insufficient, financial infrastructure is insufficient, borrowing capacity and instruments are not available, management skills for SMEs need to be developed, increased transparency appears and liquidity accessibility is limited. Not even MENA banks and financial institutions are integrated to give efficient and successful SME banking products, see Figure 7. MSME Lending Benchmarking in MENA Region (Saleem, 2013).

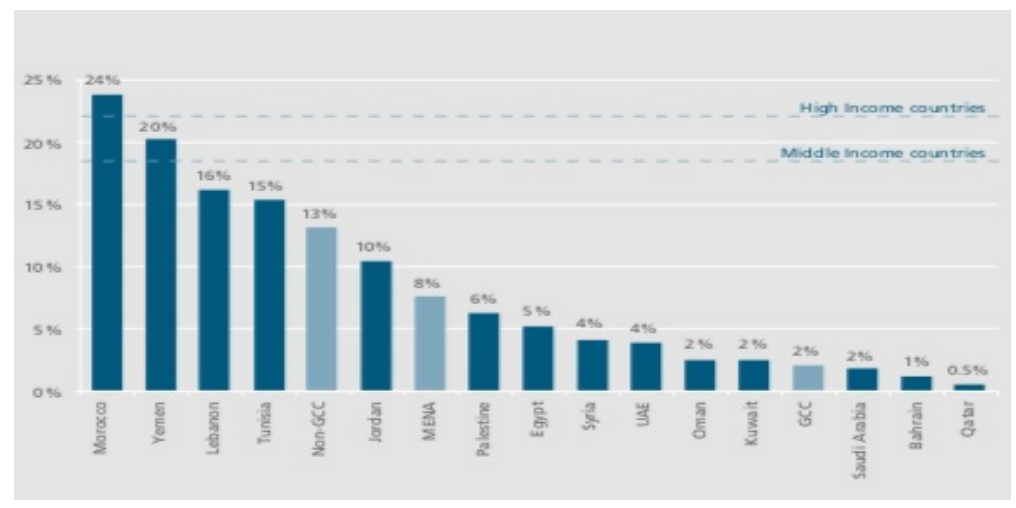

Figure 7. MSME lending benchmarking in MENA Region

Source: (Union of Arab Banks/ World Bank Financial Flagship Report 2011).

Lack of accessibility to finance resources is amongst the main challenges to the development of SMEs, which provide for around 90 precent of the enterprises and over 50 precent of the world's jobs (The International Finance Corporation [IFC], 2018). This can impact far more SMEs than it does directly through its range of financial institutions, such financial institutions, commercial banks and lending firms in over 100 other underdeveloped nations. IFC offers a wide range of banking services and products to its client FIs, including funds, securities, risk management services, export financing, lending for working capital and consulting firms. This also involves attracting financial assistance from other FIs and investment firms. IFC in the MENA offered $\$ 109$ million in long-term financing to MSME assistance client FIs during fiscal year 2018. As of June 2018 at MENA, the long-term MSME portfolio invested by IFC was $\$ 1$ billion (see Figure 8). IFC also taken 21 successful MSME-related consultancy ventures estimated at \$21.1 million (IFC, 2018). 


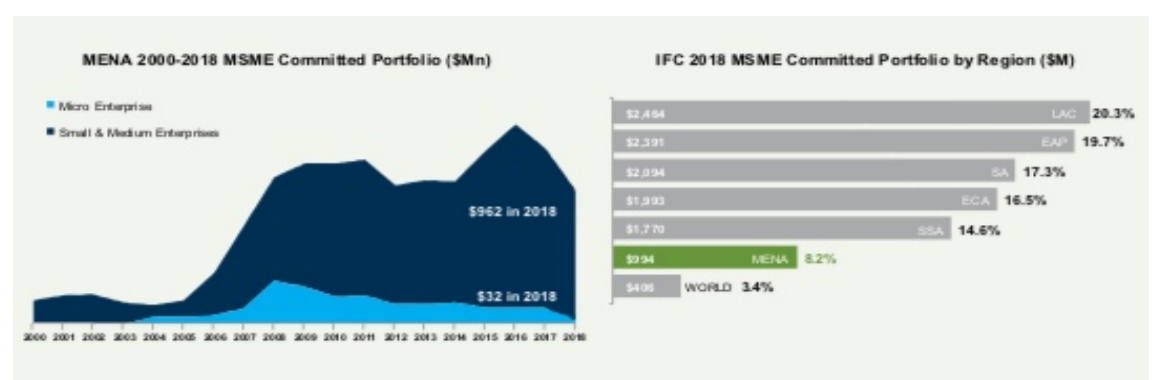

Figure 8. FY18 IFC MSME committed long-term finance portfolio (USD \$ millions)

Source: (IFC, 2018).

MENA banks reject the lack of regulation of SMEs and the poor financial structure (low credit details, poor brand influence and collateral facilities) as the major obstacles to more SME finance. Banks grumble little for regulation barriers (e.g. interest rate ceilings), increased contest on the SMEs sector or an absence of SME loan demand. Within a general environment of poor finance system, countries which are able to reinforce lender rights and also provide investors with more knowledge are able to stimulate more SME lending to SMEs in general or longer-term lending to SMEs (Rocha et al., 2011).

\section{Discussion and Conclusion}

The MENA countries have not implemented strategies and legislation to promote SME development. The lack of finance, the absence of a well-trained workforce, inadequate resources, fraud and bureaucratic barriers, lack of managerial expertise among proprietors, inefficiencies of government and infrastructural concern has inhibited the formation and development of SMEs. In order to address these challenges, it is necessary to formulate SME growth policies and to improve the capacity of people in both the public and private sectors who effectively design and implement procedures. SMEs are critical to economic development and employment, as creative firms usually try to bring new strategy into practical. SMEs in the MENA region have fewer accesses to financial services, and MENA banks are still criticized. The MENA region has thus made considerable attempts to achieve supply-side steps to tackle the problem. Although this behaviour would seem true, they neglect the fact that a pair of top and bottom blades of a scissor decide on an economic balance.

Some MENA countries implemented specific initiatives to encourage banks' lending to SMEs further. Special programs should include restrictions on bank reserves, loan incentives and limited deposit insurance initiatives in addition to the use of financial institutions. While state banks and other initiatives like guarantee schemes have sometimes contributed a crucial role in obtaining financing to SMEs in surroundings where financial structure persists limited, these same outcomes also permit MENA's economic plan in the field of SME finance to be identified. Throughout the legal / regulatory agenda, the improvement of credit information systems and creditor rights will maintain the recognizing. Deposit insurance arrangements could play a significant role, but guaranteeing that certain schemes are quite well structured and cost-effective is important. Eventually, eliminating overly stringent entry conditions and enabling the import of foreign and banking institutions with SME finance leadership will increase competition and have significant direct and indirect impact on the SME lending market.

The study offers several policy implications that reinforce the potential of SMEs to solve challenges that cannot be tackled by a single player and contribute to more lending by SMEs. In MENA, Government should develop policy initiatives and support systems to provide a strong and vibrant SME sector and increase accessibility and dissemination of SME information, promoting SMEs, access to information and markets, and adoption of new technologies, reform the legal requirements and administrative procedures for improving the performance of SMEs, such as those relating to business registration, taxation and employment, reducing bureaucracy and reform market regulations, improving transparency and accountability to reduce perceptions of corruption, and strengthening legal and regulatory systems, develop justice and governance practices and complement steps to lift productive capacity, build a strong financial infrastructure (credit registries, collateral and insolvency schemes, audit and accounting standards,) as a priority for financial growth, establishing better an effective SME financing strategy for a given country based on a detailed evaluation of its SME financing gap and the quality of its SMEs Architecture in finance, maintain convergence between policies and programs for SMEs and the general economic outlook towards strong competition, Developing the education system to ensure the capacity of professional human resources, which is vital to growth and prosperity and help to boost the technical 
capacities for SMEs. In addition, future research is required to identify the role of Islamic finance models in the financing of SMEs in MENA countries.

\section{References}

Abor, J., \& Quartey, A. (2010). Issues in SME development in Ghana and South Africa. International Research Journal of finance and Economics, 39(6), 215-228.

Ahmad, S. Z., Rani, N. S. A., \& Kassim, S. K. M. (2011). Business challenges and strategies for development of Small and Medium Sized Enterprises (SMEs) in Malaysia. International Journal of Business Competition and Growth, 1(2), 177-197.

Ahmed, K., \& Chowdhury, T. A. (2009). Performance evaluation of SMEs of Bangladesh. International Journal of Business and Management, 4(1), 126-133.

Akuru, U. B., \& Okoro, O. I. (2014). Economic implications of constant power outages on SMEs in Nigeria. Journal of Ener, 25(3), 61-66. http://doi.org/10.2139/ssrn.1968275

Arezki, R., \& Nguyen, H. (2020). Coping with a Dual Shock: COVID-19 and Oil Prices. World Bank, Washington, DC, USA. Retrieved from https://www.amse-aixmarseille.fr/sites/default/files/events/covid-19_in_developing_economies.pdf\#page=7 0

Asian SME Summit. (2009). Public Private Partnership in SME Development through Capacity Building. Policy $\&$ Research.

Avery, R. B., Bostic, R. W., \& Samolyk, K. A. (1998). The role of personal wealth in small business finance. Journal of Banking and Finance, 22, 1019-1061.

Aylin, A., Garango, P., Cocca, P., \& Bititchi, U. (2013). The development of SME managerial practice for effective performance management. Journal of Small Business and Enterprise Development, 20(1), 28-54. https://doi.org/10.1108/14626001311298402

Ayyagari, M., Beck, T., \& Demirgu"ck-Kunt, A. (2003). SMEs across the Globe. A New Database, World Bank Policy Research Working Paper $3127 . \quad$ Retrieved from https://openknowledge.worldbank.org/handle/10986/18131

Ayyagari, M., Demirguc,-Kunt, A., \& Maksimovic, V. (2006). How important are financing constraints? The role of finance in the business environment. World Bank Policy, Research Working Paper 9, No. 3820. Retrieved from https://elibrary.worldbank.org/doi/abs/10.1093/wber/lhn018

Ayyagari, M., Demirguc-Kunt, A., \& Maksimovic, V. (2014). Who creates jobs in developing countries? Small Business Economics, 43, 75-99. https://doi.org/10.1007/s11187-014-9549-5

Bari, F., Hema, A., \& Haque, E. U. (2005). SME development in Pakistan: Analyzing the constraints to growth. Pakistan Resident Mission Working Paper, 3. Retrieved from https://think-asia.org/handle/11540/6244

Batra, G., \& Tan, H. (2003). SME technical efficiency and its correlates: Cross-national evidence and policy implications. World Bank Institute Working Paper. Retrieved from https://www.scirp.org/journal/paperinformation.aspx?paperid=66226

Beck, T., Demirgüç-Kunt, A., Laeven, L., \& Maksimovic, V. (2006). The determinants of financing obstacles. Journal of International Money and Finance, 25, 932-952

Bhide, A. (1996). The questions every entrepreneur must answer. Harvard Business Review, 74, 120-130.

Bouazza, A. B., Ardjouman, D., \& Abada, O. (2015). Establishing the factors affecting the growth of small and medium-sized enterprises in Algeria. American International Journal of Social Science, 4(2), 101-115. Retrieved from http://www.aijssnet.com/journals/Vol_4_No_2_April_2015/11.pdf

Brink, A., Cant, M., \& Ligthelm, A. (2003). Problems experienced by small businesses in South Africa. 16th Annual Conference of Small Enterprises Association of Australia and New Zealand. Ballarat, Australia: University of Ballarat.

Burns, P. (2001). Entrepreneurship and small business. Great Britain.

Chusho, M. (2013). Japan's policy on small and medium enterprises and micro enterprises. Retrieved from http://wwwchusho.meti.go.jp/sme_english /outline/04/20131007.pdf

Dar, M. S., Ahmed, S., \& Raziq, A. (2017). Small and medium-size enterprises in Pakistan, definition and critical 
issues. Pakistan Business Review, 19(1), 46-70. https://doi.org/10.22555/pbr.v19i1.1245

Dong, Y., \& Men, C. (2014). SME financing in emerging markets: firm characteristics, banking structure and institutions. Emerging Markets Finance and Trade, 50(1), 120-149. https://doi.org/10.2753/REE1540-496X500107

Elhassan, O. M. (2019) Obstacles and problems facing the financing of small and medium enterprises in KSA. Journal of Finance and Accounting, 7(5), 168-183. https://doi.org/10.11648/j.jfa.20190705.16

Emine, D. (2012). Financial challenges that impede increasing the productivity of SMEs in Arab region. Journal of Contemporary Management, 1, 17-32.

Ervine, C. (2013). Core statutes on company law 2013-14. Palgrave Macmillan.

Fischer, E., \& Reuber, R. (2003). Industrial clusters and SME promotion in developing countries. In G. Wignaraja (Ed.), Competitiveness Strategy and Industrial Performance: A Manual for Policy Analysis, 143-178. London: Routledge.

Gibson, T., \& Vaart, H. J. (2008). Defining SMEs: A less imperfect way of defining small and medium enterprises in developing countries. Retrieved from https://www.brookings.edu/wp-content/uploads/2016/06/09_development_gibson.pdf

Gonzales, E., Hommes, M., \& Mirmulstein, M. L. (2014). MSME country indicators. International Finance Corporation. Retrieved from http://ifcwebapp.github.io/msmecountryindicators/analysis\%20note.pdf

Hewitt, T., \& Wield, D. (1992). Technology and industrialization. In Hewitt, T., Johnson, H., \& Wield, D., (Eds.), Industrialization and Development. Oxford University Press.

Hu, Q., Mason, R., Williams, S. J., \& Found, P. (2015). Lean implementation within SMEs: a literature review. Journal of Manufacturing Technology Management, 2(7), 980-1012. https://doi.org/10.1016/j.orp.2018.100089

Hussain, I., Farooq, Z., \& Akhtar, W. (2012). SMEs development and failure avoidance in developing countries through public private partnership. African Journal of Business Management, 6(4), 1573-1581. https://doi.org/10.5897/AJBM11.2526

Kamunge, M. S., Njeru, A., \& Tirimba, O. I. (2014). Factors affecting the performance of small and micro enterprises in Limuru Town Market of Kiambu County, Kenya. International Journal of Scientific and Research Publications, 4(12), 1-20.

Karadag, H. (2015). The role and challenges of small and medium-sized enterprises in emerging economies: An analysis from turkey. Business and Management Studies, 1(2), 179-188. https://doi.org/10.11114/bms.v1i2.1049

Keskin, H., Senturk, C., Sungur, O., \& Kiris, H. M. (2010). The importance of SMEs in developing economies. (pp. 183-192). The 2nd International Symposium on Sustainable Development.

Khalique, M., Isa, A. H. B. M., Shaari, N., Abdul, J., \& Ageel, A. (2011). Challenges faced by the small and medium enterprises in Malaysia: An Intellectual capital perspective. International Journal of Current Research, 3(6), 398-401.

King, K., \& McGrath, S. (2002). Globalization, enterprise and knowledge: Educational training and development. International Review of Education, 50(1), 74-76.

Lee, J. (2001). Education for technology readiness: Prospects for developing countries. Journal of Human Development, 2(1), 115-151. https://doi.org/10.1080/14649880120050219

Lin, Y. F. (2007). Developing small and medium bank to improve financial structure. Working paper, China Center for Economic Research, Peking University (in Chinese). https://doi.org/10.13140/RG.2.1.4737.2563

Lucas, R. (1993). Making of a Miracle. Econometrics, 61, 251-272. https://doi.org/10.2307/2951551

Luetkenhorst, W. (2004). Corporate social responsibility and the development agenda. Intereconomics, 39(3), 157-168. https://doi.org/10.1007/BF02933583

Mahmood, S. (2008). Corporate governance and business ethics for SMEs in developing countries: Challenges and way forward. Paper presented at the International Society of Business, Economics, and Ethics World Congress 2008, Cape Town, South Africa, July 15-18.

Makhlouf, M. (2017). Islamic banking opportunities across small and medium enterprises in MENA: Executive 
summary, World Bank Group, Washington, DC. Retrieved from http://documents.worldbank.org/curated/en/997581487153582013/Islamic-banking-opportunities-across-sm alland-medium-enterprises-in-MENA-executive-summary

Mambula, C. (2002). Perceptions of SME growth constraints in Nigeria. Journal of Small Business Management, 40(1), 58-65. https://doi.org/10.1111/1540-627X.00039

McElwee, G., \& Warren, L. (2000). The relationship between total quality management and human resource management in small and medium-sized enterprises. Journal of Strategic Change, 9(7), 427-435. https://doi.org/10.1002/1099-1697

Morse, E. A., Fowler S. W., \& Lawrence, T. B. (2007). The impact of virtual embeddedness on new venture survival: Overcoming the liabilities of newness. Entrep. Theory Pract, 1, 139-159. https://doi.org/10.1111/j.1540-6520.2007.00167.x

Muriithi, S. M. (2017). African small and medium enterprises: Contributions, challenges and solutions. European Journal of Research and Reflection in Management Sciences, 5(1), 36-48.

Nag, D., \& Das, N. (2015). Development of various training methods for enhancing effectiveness and skill development among micro entrepreneurs in India. Journal of Enterpreneurship Education, 18(1), 1-18.

Ndiaye, N., Razak, L. A., Nagayev, R., \& Ng, A. (2018). Demystifying small and medium enterprises' performance in emerging and developing economies. Borsa Istanbul Review, 18(4), 269-281. https://doi.org/10.1016/j.bir.2018.04.003

Obokoh, L. O., \& Goldman, G. (2016). Infrastructure deficiency and the performance of small- and medium-sized enterprises in Nigeria's Liberalised Economy. Acta Commercii, 16(1, a339), 1-10. https://doi.org/10.4102/ac.v16i1.339

OECD. (2000). Small and Medium-sized Enterprises: local Strength, global reach. OECD Policy Review, 1-8.

OECD. (2020). COVID-19 crisis response in MENA countries. Retrieved from https://read.oecd-ilibrary.org/view/?ref=129_129919-4li7bq8asv\&title=COVID-19-Crisis-Response-in-ME NA-Countries

Pasanen, M. (2007). SME growth strategies: organic or non-organic? Journal of Enterprising Culture, 15(4), 317-338. https://doi.org/10.1142/S0218495807000174

Perera, D., \& Chand, P. (2015). Issues in the adoption of international financial reporting standards for small and medium-sized enterprises. Advances in Accounting, 31(1), 165-178. https://doi.org/10.1016/j.adiac.2015.03.012

Piperopoulos, P. G. (2016). Entrepreneurship, innovation and business clusters. Routledge.

Quartey, P., Turkson, E., Abor, J. Y., \& Iddrisu, A. M. (2017). Financing the growth of SMEs in Africa: What are the constraints to SME financing within ECOWAS? Review of Development Finance, 7, 18-28. https://doi.org/10.1016/j.rdf.2017.03.001

Rocha, R., Farazi, S., Khouri, R., \& Pearce, D. (2011). The status of bank lending to SMEs in the Middle East and North Africa Region: Results of a joint survey of the Union of Arab Banks and the World Bank. Policy Research Working Paper 5607. https://doi.org/10.1596/1813-9450-5607

Romijn, H. (2001). Technology support for small industry in developing countries: A review of concepts and project practices? Oxford Development Studies, 29(1), 57-76. https://doi.org/10.1080/13600810124790

Rosenbusch, N., Brinckmann, J., \& Bausch, A. (2011). Is innovation always beneficial? A Meta-Analysis of the Relationship between innovation and performance in SMEs. Journal of Business Venturing, 26(4), 441-457. https://doi.org/10.1016/j.jbusvent.2009.12.002

Saleem, Q. (2013). Overcoming constraints to SME development in MENA countries and enhancing access to finance. IFC.

Saqib, N. (2014). Institutional performers for processing infrastructure reforms for SMEs. Business \& $\begin{array}{lllll}\text { Entrepreneurship } & \text { Journal, } & \text { R(2), } & \text { Retrieved }\end{array}$ https://ideas.repec.org/a/spt/busent/v3y2014i2f3_2_2.html

Shen, Y., Shen, M., Xu, Z., \& Bai, Y. (2009). Bank size and small- and medium sized enterprise lending: Evidence from China. World Development, 37(4), 800-811. https://doi.org/10.1016/j.worlddev.2008.07.014

Sikka, P. (1999). Technological innovations by SMEs in India. Technovation, 19(5), 317-321. 
https://doi.org/10.1016/S0166-4972 (98)00126-6

Stepanyan, V., Abajyan, G., Ndoye, A., \& Alnasaa, M. (2019). Enhancing the role of SMEs in the Arab World-some key considerations. International Monetary Fund Washington, D.C.

Storey, D. J. (1994). Understanding the small business sector. Routledge, London.

Subrahmanya, M. H. B., Mathirajan, M., \& Krishaswamy, K. N. (2010). Importance of technological innovation for SME growth: Evidence from India. In UNU-MERIT working paper series. Retrieved from http://www.merit.unu.edu/publications/wppdf/2010/wp2010-007.pdf

The International Finance Corporation. (2018). Middle East and North Africa: IFC financing to micro, small and medium Enterprises. IFC.

The United Nations Office for the Coordination of Humanitarian Affairs. (2020). The impact of COVID-19 on the Arab region an opportunity to build back better. Retrieved from https://unsdg.un.org/sites/default/files/2020-07/sg_policy_brief_covid19_and_arab_states_english_version_ july_2020.pdf

Wang, Y. (2016). What are the biggest obstacles to growth of SMEs in developing countries? - An empirical evidence from an enterprise survey. Borsa Istanbul Review, 16(3), 167-176. https://doi.org/10.1016/j.bir.2016.06.001

World Business Council for Sustainable Development. (2007). Promoting SMEs for sustainable development. WBCSD, July, 2007, p2.

Yusuf, S. (2003). Innovative East Asia: The future of growth. Washington, D. C: World Bank. Retrieved from https://openknowledge.worldbank.org/handle/10986/15158 License: CC BY 3.0 IGO

Zafar, A., \& Mustafa, S. (2017). SMEs and its role in the economic and socio-economic development of Pakistan. International Journal of Academic Research in Economics and Management Sciences, 6(4), 1-16. https://doi.org/10.6007/IJARAFMS/v7-i4/3484

Zimmerer, T., Searborough, N., \& Wilson, D. (2008). Essential of entrepreneur1/2ship and small business management (5th ed.). New Jersey: Prentice Hall, Upper Saddle River.

\section{Copyrights}

Copyright for this article is retained by the author(s), with first publication rights granted to the journal.

This is an open-access article distributed under the terms and conditions of the Creative Commons Attribution license (http://creativecommons.org/licenses/by/4.0/). 